\title{
Review Work on Body Weight and Egg Production Performance of Chickens in Ethiopia
}

\author{
Gebremariam B.* Girma F. \\ College of Agriculture and Natural Resources, Raya University, Ethiopia
}

\begin{abstract}
*Corresponding author: Brhane Gebremariam, Msc. In Animal Genetics and Breeding, College of Agriculture and Natural Resources, P. O. Box 42, Raya University, Ethiopia.

Abstract

Different breeds of exotic chickens were imported to Ethiopia with the aim of improving chicken productivity. Moreover, one way of improving low genetic potential of local chickens is crossbreeding programs of local chickens with exotic chicken breeds. For further improvement in production traits, understanding performance of economic traits in chicken is important for the formulation of breeding plans. Therefore, the objective of this review paper is to review egg and body weight performance of chickens in Ethiopia. Breed of chicken used, environmental conditions, and management practices are the main factor that affects chicken productivity. The average egg production and body weight performance of chickens is higher in exotic breed followed by cross and local ones. However, poor performance of exotic chickens is observed in situations where the breeds are poorly managed. The performance of crossbreds reduces gradually as the percent of genes goes beyond 50 but the management gets down. With regard to local ones, better management and proper breeding technique do have a chance for upgrading. Therefore, better management, proper breeding activities and regulatory laws should be imposed to enhance chicken productivities.
\end{abstract}

Keywords: Egg, Body weight, Local, Exotic, Crossbreed, Chicken

DOI: $10.7176 / \mathrm{JBAH} / 9-8-03$

Publication date: April $30^{\text {th }} 2019$

\section{INTRODUCTION}

In Ethiopia, there are several exotic chickens like Rhodo Island Red, Australop, New Hampshire, White Leghorn introduced and disseminated since 1950's. The purpose of introducing these breeds is for the aim of improving local chicken's productivity [1]. Hence, higher learning institutions, research organizations, ministry of agricultures and non-governmental organizations were participating in disseminating to the rural farmers and urban based small scale poultry producers [2]. However, lack of performance data and overall management is a constraint [3]. Moreover, most of the exotic chickens are not high yielding under village production system [4]. Hence, crossbreeding was used as a way to improve performance of local chickens $[5,6]$. However, increasing productivity using this common approach is now being reconsidered due to the fact that the exotic chickens are not productive under low in put conditions and place native breeds at risk of genetic dilution [4]. Therefore, this review aims to review egg and body weight performance of chickens in Ethiopia.

\section{BODY WEIGHT AND EGG PRODUCTION PERFORMANCE OF CHICKENS IN ETHIOPIA}

\subsection{Local}

The mean body weight of grower male chicken is 1.05kilogram [7]. Moreover, 1316gram and 1180gram of average body weight of local hens is recorded [9]. In addition to this, mature male of (1.812kilogram and 1.694 kilogram) and mature female of (1.37kilogram and 1.35kilogram) is reported for mid and low altitude respectively [10]. Beside to this, 2049.07 gram of cock weight is observed for North West Ethiopia [8]. The variation and poor performance in body weight of these chickens is due to both genetic and noon genetic factors [11]. Number of eggs per clutch is reported $14.9 \mathrm{egg} / \mathrm{hen} / \mathrm{clutch}$ [7], $18 \mathrm{eggs} / \mathrm{hen} / \mathrm{clutch}$ [12], 13.3 eggs/hen/clutch [13], 13.6 (9-18) eggs/hen/clutch [10], $12.92 \mathrm{eggs} / \mathrm{hen} / \mathrm{clutch}$ [14], 10-18 eggs/hen/clutch [15] and $12.64 \mathrm{eggs} / \mathrm{hen} / \mathrm{clutch}$ which is almost related [16]. Moreover, mean egg production is 27-45 eggs [17], 43.4 eggs [10], 49.51 eggs [16] and 50.8 eggs [13]. Therefore, additional supplementation of feed at the time of sowing and during and after harvesting is necessary to obtain higher egg production [11].

\subsection{Exotic}

Knowledge on performance of economic traits is important in formulation of breeding plan and chickens improvements [18]. Some of the factors which affect chicken production performance are breed type, environmental condition, poultry house, feed and feeding managements [1]. Moreover, extension options together with improved exotic chickens are necessary for productive and adaptive characters [19, 20]. The average body weight at sexual maturity of Fayoumi chicken is 1197gram [21]. Besides, 155.50 days, 1240g, 163.63days, $1253 \pm 16.42 \mathrm{~g}$, of age and weight at sexual maturity is obtained from Fayoumi chickens, respectively [22]. The advantage of this exotic chicken is its high growth and early maturing which reduces production cost 
[1]. Hence, average age and weight at sexual maturity of Fayoumi is 183.55 .60 days and $1215 \pm 11.12 \mathrm{~g}$, respectively [15]. Moreover, the average body weight of adult females for Bovans Brown and KoekKoek chicken is $1.55 \mathrm{~kg}$ and $1.64 \mathrm{~kg}$ respectively [23].

Egg number is one of the major traits of economic importance which affects by many factors like breed, feed consumption, disease and management factors $[24,25]$. The performance of White Leghorn, Rhode Island Red and Fayoumi chicken under village household condition of northern Ethiopia is 173eggs, 185 eggs and 144 eggs/year/hen, respectively [1]. Moreover, there is 82 eggs/hen for White Leghorn based on evaluation under rural household condition for 20 weeks with additional supplements [2]. However, in high standard management there is $60-70 \%$ of the performance as recommended by the breeder company is obtained [26]

\subsection{Crossbred}

Crossbreeding of Bovans Brown chickens with local chickens raise the gene by 0.25 or $0.5 \%$ [27]. Moreover, the body weight performance of 50 percent Bovans-Brown cross has superior performance than $25 \%$ bovans brown cross. However, the superiority in performance decreases gradually as percentage of gene increases. Rhode Island Red Cross has high body weight performances [21,28]. The average body weight of 1169 gram at sexual maturity of F1 crosses of naked-neck and Lohmann White chicken breeds is also reported [6].

The egg production performance of Rhode Island Red crosses is higher than Rhode Island Red breed under traditional production systems [29]. This variation might come from the environment hindering to allow the full genetic expressions [30]. In addition to this, there is average egg weight (41 g) in crosses between White Leghorn and Nigerian indigenous chickens [5]. In Ethiopia, number of eggs from crossbred hens of Yarkon and any local (129 eggs), Fayoumi and Necked Neck (119 eggs), Rhode Island Red and any local chicken (90.8 eggs) is indicated [16].

\section{CONCLUSIONS AND RECOMMENDATIONS}

In Ethiopia, local chickens show poor performance of egg and body weight. However, in situation of good management and handling, they have the potential to improve. The variation with in breed performance might be due to different factors like feeding, concern and care of farmers to their chickens. Hence, to improve productive performance of local chickens, extra effort in the management such as housing, breeding, feeding and health care is needed. Despite exotic chickens are characterized with higher body weight and egg production relative to local and their crosses but better management is demanded to a certain it . Therefore, exotic chickens having better productivity, adaptability and disease resistance should be introduced together with proper extension packages. It is found as a common approach to enhance performance of local chickens through crossbreeding even if this approach needs special attention with regard to management and breeding. Hence, the fear to the risk of genetic dilution should be avoided using proper breeding activities and regulatory laws.

\section{ACKNOWLEDGEMENTS}

I am grateful to Raya University for providing internet access. I am also indebted to all my colleagues who devoted their time, energy and their resources for sharing vital comments and suggestions.

\section{REFERENCES}

1. Abraham L, Yayneshet T (2010) Performance of exotic and indigenous poultry breeds managed by smallholder farmers in northern Ethiopia. Livestock Research for Rural Development 22:7.

2. Solomon D (2008) Ethiopia: Poultry sector country review. FAO, Rome, Italy. $\mathrm{ftp} / / \mathrm{ftp}$. fao.org/docrep/fao/011/ai320e/ai320e00.pdf, retrieved on 16 May 2015.

3. Fisseha M, Abera M, Tadelle D, (2010a) Assessment of village chicken production system and evaluation of the productive and reproductive performance of local chicken ecotype in Bure district, Northwest Ethiopia. African Journal of Agricultural Research 5:1739-1748.

4. FAO (2010) Chicken genetic resources used in smallholder production systems and opportunities for their development. Rome, Italy.

5. Ajayi FO (2010) Indigenous chicken: a valuable genetic re-source for meat and egg production. Asian Journal of Poultry Science 4: 164-172.

6. Aberra M, Maak S, Schmidt R, Von Lengerken G (2011a) Effect of longterm heat stress on some performance traits and plasma enzyme activities in Naked-neck chickens and their F1 crosses with commercial layer breeds. Livestock Science Journal141: 227-231.

7. Mekonnen G (2007) Characterization of small holder poultry production and marketing system. Msc. Thesis, Hawassa University, Hawassa, Ethiopia, 89pp.

8. Halima H (2007) Phenotypic and genetic characterization of indigenous chicken populations in northwest Ethiopia. PhD Thesis, University of Free State, Bloemfontein, South Africa 176pp.

9. Bogale K (2008) In situ characterization of local chicken ecotype for functional traits and production 
system in Fogera woreda, Amhara regional state. Msc. Thesis, Haramaya University, Ethiopia 123.

10. Alem T (2014) Production and reproduction performance of rural poultry in low altitude and mid altitude agro ecological zones of Central Tigray, Northern Ethiopia. British Journal of Poultry Science 3: 6-14.

11. Brhane G, Hailu M, Tikabo G (2017) Indigenous chicken production system and breeding practice in southern Tigray, North Ethiopia. Poultry Fish Wildlife Sciences 5: 179.

12. Melese G, Melkamu B (2013) Assessment of chicken production under farmer's management condition in East Gojam zone, Amhara regional state, Ethiopia. International Journal of Science and Research 3:2-8.

13. Nebiyu Y, Berhan T, Kelay B (2013) Characterization of village chicken production performance under scavenging system in Halaba district of southern Ethiopia. Ethiopian Veternary Journal 17: 69-80.

14. Meseret M (2010) Characterization of village chicken production and Marketing system in Gomma district, Jimma zone. Msc. Thesis, Jimma University, Ethiopia 110 pp.

15. Samson L, Endalew B (2010) Survey on village based chicken production and utilization system in Mid Rift Valley of Oromia, Ethiopia. Global Veternary Journal 5: 198-203.

16. Addis G, Malede B (2014) Effect of gene segregation on existing performance of chicken ecotypes in Ethiopia. Middle East Journal of Scientific Research 21:675-680.

17. Mulugeta A, Tebkew A (2011) Evaluation of indigenous chicken productivity by using a questioner survey, in selected Chagni town, Awi administrative zone, Amhara Region, Ethiopia. World Journal of Agricultural Science 1:26-35.

18. Gondwe TNP (2005) Characterization of local chicken in low input low output production systems. PhD thesis, Georg August University, Gottingen 125pp.

19. DZARC (Debre Zait Agricultural Research Center) (2007) Annual research report. Debre Zeit, Ethiopia.

20. Wilson R (2010) Poultry production and performance in the Federal Democratic Republic of Ethiopia. World's Poultry Science Journal 66.

21. Zaman MA, Sørensen P, Howlider MAR (2004) Egg production performance of three crossbreeds under semi-scavenging system of management. Livestock Research for Rural Development 16: 8.

22. Khan MKI, Khatun MJ, Bhuiyan MSA, Sharmin R (2006) Production performance of Fayoumi chicken under intensive management. Pakistan Journal of Biological Science 9: 179-181.

23. Desalew T (2012) Management practices, productive performances and egg quality traits of exotic chickens under village production system in East Shewa. Msc. Thesis, Addis Ababa University, Ethiopia 70pp.

24. Hailu M, Grimachew S, Mehammed N (2012) Challenges and prospects of village-based exotic chicken development strategy in Amhara Regional State, Northwest Ethiopia. Global Journal of Science Frontier Research 12: 41-48.

25. Olawumi S, Dudusola I (2010) Effects of genotype and housing on reproductive performance of two strains of commercial layers in the derived Savannah Zone of Nigeria. Publication of Nasarawa State University, Keffi 6:102-109.

26. Nigussie D, Reta D, Teklewold H, Aliye S (2006) Transforming village poultry systems into small agrobusiness ventures: a partnership model for the transfer of livestock technologies in Ethiopia. Livestock Research for Rural Development 18:169.

27. Ssewannyana E, Ssali A, Kasadha T, Dhikusooka M, Kalema P (2004) Characterization of indigenous chickens of Uganda, Kampala, Uganda. Journal of Animal and Plant Science 1:33-37.

28. Rahman M, Baqui MA, Howlider MAR (2004) Egg production performance of RIR $\times$ Fayoumi and Fayoumi $\times$ RIR crossbreed chicken under intensive management in Bangla-desh. Livestock Research for Rural Development 16: 92.

29. Alewi M, Melesse A, Teklegiorgs Y (2012) Cross breeding effect on egg quality. Arch. Geflügelk. 53: 93-101.

30. Miazi OF, Miah G, Miazi MM, Uddin MM, Hassan MM, Faridahsan Md (2012) Fertility and hatchability of Fayoumi and Sonali chicks. Scholary Journal of Agricultural Science 2: 83-86. 